\title{
BUYING SCENERY: LAND ACQUISITIONS FOR THE NATIONAL PARK SERVICE**
}

\author{
JOSEPH L. SAX**
}

The National Parks are enclaves of preservation adrift in a sea of development. Inevitably conflicts arise, for even the most conventional private land uses are frequently incompatible with the historic, archeological, and ecological preservation mandates under which the park system operates. ${ }^{1}$ Where a conflict results from activity on other federal lands, such as the National Forests, its resolution is in theory (though rarely in practice) simple enough. The government need only decide which of its own competing policies to prefer in a given situation. ${ }^{2}$ But when private land uses intrude upon park protection, a much more delicate problem arises.

Congress is understandably reluctant to compel communities and property owners to arrange their affairs simply to accommodate the

* This paper was originally presented as the Brainerd Currie Memorial Lecture at the Duke University School of Law, on March 27, 1980.

** Professor of Law, the University of Michigan; A.B. 1957, Harvard University; J.D. 1959, the University of Chicago.

THE FOLLOWING CITATIONS WILL BE USED IN THIS ARTICLE:

Hearings on Dep't of the Interior and Related Agencies for Fiscal 1979 Before the Subcomm. on Dep't of Interior and Related Agencies of the House Comm. on Appropriations, 95th Cong., 2d Sess. (1979), hereinafter cited as Hearings,

Sax, Helpless Giants: The National Parks and the Regulation of Private Lands, 75 MicH. L. Rev. 239 (1976), hereinafter cited as Sax;

National Park Service, Land Acquisition Policy, 44 Fed. Reg. 24,790 (1979), hereinafter cited as Land Acquisition Policy.

1. The National Park Service Organic Act, 16 U.S.C. $\$ 1$ (1976), is the general authority under which the park system operates. Each facility, however, is also governed by the particular language of its establishing act. These laws are compiled in Title 16 of the United States Code. In referring to units of the National Park System, this Article includes all those areas-about 360 in number-listed in National Park Service, U.S. Dep'T Of THE INTERIOR, INDEX of National Park System and Related Areas (1979).

2. The problems range from hicensing of nuclear plants by the Nuclear Regulatory Commission (Indiana Dunes National Lakeshore) to commercial overflights regulated by the Federal Aviation Authority (Colorado National Monument), air pollution from coal-burning plants that involves the Environmental Protection Agency (Capitol Reef National Park) to geothermal leasing on adjacent land governed by the United States Forest Service (Yellowstone National Park). A useful survey is provided in NPCA Adjacent Lands Survey (pts. 1-3), National Parks AND Conservation Magazine, Mar. 1979, at 4, Apr. 1979, at 4, Nov. 1979, at 21. The typical device for resolving federal interagency conflicts is a contract-kike document called a Memorandum of Understanding. 
needs of the parks. ${ }^{3}$ Federal zoning (the very term makes landowners gag) would in some instances intrude sharply upon local self-governinent and adversely affect the value of private holdings. Exercise of the eminent domain power is not a fully satisfactory solution either, for people are nearly as unhappy to be removed from their land-even with full compensation-as they are to be regulated. ${ }^{4}$ Neither does local land use regulation usually meet the parks' needs, for the constraints landowners are willing to impose upon themselves through local government frequently fall far short of the protection that Congress and the National Park Service believe is minimally required. ${ }^{5}$ Yet the federal government can hardly stand idly by and permit the crown jewels of the public domain to become whatever the citizens of Jackson, Wyoming-or the owners of some strategically located mining or forest lands-are prepared to tolerate.

The incompatibility of private land development with public parks is not a new problem, although it is more severe now than ever before. ${ }^{6}$

3. Congress clearly possesses constitutional authority to regulate private lands for the protection of the parks. Sax 245-58.

4. See The Establishment of a Jackson Hole Scenic Area: Hearings on H.R. 9135 Before the Subcomm. on National Parks and Insular Affairs of the Senate Comm. on Imtcrior and Insular Affairs, 95th Cong., 2d Sess. 37-39 (1978) (unpublished, on file with the author).

5. Much of the information in this Article is taken from Superintendent Survey, a questionnaire survey made by the author in 1980 of all superintendents of national park system units. The original survey questionnaires are on file with the author. Because the survey data are not genterally accessibie to readers, references will not generally be made to particular questionnaires, and factual data are frequently recited, drawn from questionnaires, without a footnote so stating in every instance. The author, however, invites inquiries from interested readers, and will be glad to supply detailed references to the survey data.

The great majority of Superintendent Survey responses indicate that nearby communities are not willing to impose zoning on themselves sufficient to protect the parks against incompatible private developments. In some places, such as Cape Cod and Fire Island National Seashores, established communities have adopted federally recommended zoning under threat of condemnation. Sax $242 \mathrm{n} .19$. In several new park system areas, the authorizing legislation calls for federally-encouraged local management or zoning. See Jean Lafitte National Historic Park, 16 U.S.C. $\S 230$ a(b) (Supp. II 1978); Lowell National Historic Park, 16 U.S.C. § 410cc-11(b) (Supp. II 1978); San Antonio Missions National Historic Park, 16 U.S.C. \$410ee(b)(2) (Supp. Il 1978); Santa Monica Mountains National Recreation Area, 16 U.S.C. $\$ 460 \mathrm{kk}$ (n) (Supp. II 1978). See also Pinelands National Reserve, 16 U.S.C. \& 471 li(d), (e), (f) (Supp. II 1978). Whether these laws will encourage non-federal land use regulation remains to be seen. A Superintendent Survey from Santa Monica Mountains National Recration Area expressed some skepticism. A pending case at Jean Lafitte National Historic Park challenges the federal guidelines as a taking of property. Bayou des Familles Dev. Corp. v. United States, No. $79-4324$ (E.D. La., filed Nov. 2, 1979). See also Halpert v. Udall, 231 F. Supp. 574 (S.D. Fla. 1964), affd, 379 U.S. 645 (1965).

6. NPCA Adjacent Lands Survey, supra note 2. One reason is the large number of new units established in the eastern United States during the last two decades, where there is more developinent and more surrounding private land. In the West, the dominant threats are from energy developments. 
Recent surveys reveal that park managers believe private land developments within or near park boundaries threaten their parks. ${ }^{7}$ Congress has yet to articulate a comprehensive national scheme to meet the problems of incompatible private land uses. ${ }^{8}$ The purpose of this Article is to identify the range of problems faced by the National Park System, to examine current congressional responses (focusing on practical problems rather than merely on legal devices), and to suggest some clianges in present policy applicable to private lands both within and outside park boundaries. ${ }^{9}$

\section{The Problems}

As might be expected in a system that has been growing incrementally for more than a liundred years, with eacli park established by an individual law, the statutory provisions relating to control and acquisition of private lands are enormously diverse. To some extent, differential treatment is appropriate, for the park system itself is dazzlingly diverse. The system covers locations from Independence National Historical Park, in the midst of Philadelphia, to Joshua Tree National Monument, set in the heart of the California Desert. At Cape Cod, Indiana Dunes, and Fire Island Seasliores, long-established vacation communities are within the park boundaries, while at Chaco Canyon National Monument the park neighbor is an Indian Tribe, and at Organ Pipe Cactus National Monument the adjoining landowners are Mexican citizens. Some national parks, like the Joln F. Kennedy National Historic Site, are less than an acre in size; Yellowstone National Park encompasses more than two million acres.

7. Superintendent Survey, supra note 5; NPCA Adjacent Lands Survey, supra note 2. National Park Service, Dep't of the Interior, Report to the Congress on State of the Parks (1980). See also Shands, Federal Resource Lands and their Neighbors (1980) (printed by The Conservation Foundation, Washington, D.C.).

8. There is no general statute dealing with land acquisition to meet incompatible use problems. Sometimes, however, Congress deals with particular land acquisition problems. See, e.g., Glen Canyon National Recreation Area, 16 U.S.C. $\S 460 d d-1$ (a) (1976) (state and local government lands may be acquired only by donation or exchange, not by purchase or condemnation); Upper Delaware Scenic and Recreational River, I6 U.S.C. § I274(19) (Supp. II I978); National Parks and Recreation Act of 1978, Pub. L. No. 95-625, 92 Stat. 3467 (limits on acreage). The National Park Service has recently issued a Revised Land Acquisition Policy of general application. Land Acquisition Policy 24,790. Most park officials have drafted land acquisition plans as required by the new policy. The plans apply, however, only to lands within park boundaries, for in general those are the only lands Congress pernits the Park Service to acquire without making a legislative boundary change. See, e.g., Redwood National Park, 16 U.S.C.A $\$ 74 c(a)$ (West Supp. 1979).

9. A recent critique is the Comptroller General Report, The Federal Drive to Acquire Private Lands Should be Reassessed, General Accountimg Office, CED-80-14 (Dec. 14, 1979). See also Comptroller General Report, Federal Protection and Preservation of Wild and Scenic Rivers is Slow and Costly, CED-78-96 (May 22, 1978). As this Article will make clear, I am persuaded that the Comptroller General's criticisms are largely misdirected. 
Political realities also create much variety. National parks are rarely thrust upon an unwilling community, and many of the laws establishing parks were carefully tailored to obtain the acquiescence of the host community and its congressional representatives. ${ }^{10}$ In some instances strict limits on land acquisitions have been inserted in the establisling statutes, precisely to protect developmental opportunities for nearby landowners. ${ }^{11}$ At times, park boundaries are drawn to exclude private holdings within a park, creating wholly surrounded enclaves; ${ }^{12}$ at other times, boundaries are established-quite irrationally from a inanagerial or ecological point of view-so that private uses mevitably adversely affect the purposes for which the park was created. ${ }^{13}$ On occasion, such political and economic compromises are so seriously misguided that Congress later rectifies the error at a very high price. Perhaps the best-known inodern example is the Redwoods National Park im California. The park was established in 1968 after an intense dispute between park proponents and local lumber companies; only a part of the watershed of Redwood Creek, however, was encompassed. Continued timber harvesting on the excluded land was so harmful to the park that ten years later Congress added 48,000 acres to the park at a cost that may reach half a billion dollars. ${ }^{14}$

Full protection of the parks from incompatible development is nevertheless plamly impracticable. In much of the West, park protection is inextricably linked to questions of national energy policy. To protect the Everglades adequately would require federal control of all land use planning in southernmost Florida. Even on a smaller scale, agonizing questions are presented as to whether, and to what extent, community development should be subordinated to the needs of the parks. Lookout Mountain in Chattanooga National Military Park is in the path of the City of Chattanooga's residential growth. The ongoing transformation of Teton County, Wyoining froin a traditional western ranching area to an urbanizing resort and vacation community poses threats to Grand Teton National Park. Conversely, at Glacier Bay National Monument in Alaska, the inclination of the Park Service to move administrative facilities outside park boundaries intrudes on the desires of the community at Gustavus to inaintain its traditional lifestyle.

10. See, e.g., Upper Delaware Scenic and Recreation River Act, 16 U.S.C. § 1274(19) (Supp. II 1978). See also Superintendant Survey, supra note 5 (Olympic National Park), and letter from Superintendant Roger J. Contor to the author (Feb. 15, 1980).

11. See note 8 supra.

12. One example is Lost Creek Ranch at Grand Teton National Park. See National Park Service, U.S. Dep't of the Interior, Boundary Study, Grand Teton National Park 40 (Sept. 1975).

13. See note 14 infra.

14. The Tragedy of Redwood National Park, Natural Resources Defense Council Newsletter (July/Aug., 1977). See 16 U.S.C. § 79b(a) (Supp. 11 1978). 
No general principle can possibly resolve all these diverse problems. This Article will deal with one limited, but nonetheless significant, aspect of the problem: As to those private lands and private land uses that Congress is prepared to control, ${ }^{15}$ what policy will best assure adequate park protection, fair treatment of landowners, and a wise use of taxpayers' money? To address those questions, one must first understand current land acquisition policy and its background.

\section{A. Congressional Land Acquisition Policy.}

In the infancy of the National Parks System, when parks were largely carved out of the existing public domain in the West, the policy was rather simple. ${ }^{16} \mathrm{~A}$ boundary was drawn around the land area intended to be managed and protected as park land. Inside the boundary was federally owned land subject to the preservation mandate, and outside was other (also federally owned) land. Because niost of this outside land was not developed or exploited, its use was usually of little moment to the National Parks; indeed, it often served as a protective buffer. Conversely, the land within the boundaries was fully under the control of the National Park Service.

Of course, matters were never in fact quite so simple. Even within federal enclaves, soine tracts-for example, liomesteads-had passed into private ownership prior to the time a park was established. ${ }^{17}$ The Park Service sonietimes acquired these private lioldings by purchase, donation, or condemnation; at other times the lands were left in private ownership as "inholdings." The inholdings were allowed to reinain for various reasons. ${ }^{18}$ In sonie instances, they were originally residences,

15. Congress coutrols acquisitions by requiring advance permission to be obtained, tract by tract, froin the governing congressional committees. See Sax 242 n.21. But see Letter from Phillip Burton, Chairman of the House Subcommittee on National Parks and Insular Affairs, to William Whalen, Director, National Park Service (July 19, 1977) (requiring only quarterly reports). As a result, private lands in and near the parks that threaten to be developed incompatibly can be identified well in advance of actual development. See note 72 infra.

Major funding for acquisitions is provided largely by the Land and Water Conservation Fund. See The Federal Drive to Acquire Private Lands, supra note 9, at 3-6. The fiow of money, however, is regulated by the Office of Management and Budget. We are advised that there are no Land and Water Conservation Funds available for inholding acquisitions Service-wide except in exceptionally critical instances of threatened or actual incounpatible uses. Letter from Robert C. Haraden, Superintendent, Big Bend Natioual Park, to author, Ref. No. L 1417 (Mar. 31, 1980). See text accompanying notes 18-20 infra. $277 f$.

16. A review of past land acquisition practice, somewhat outdated now, appears in Hearings

17. Sax 263 n.123.

18. See J. Ise, Our National. Park Policy: A Critical History 66, 106, 112, 134, 137 , $170,213,216,225,246,247,284,318,334,338,381,408,483$ (1961). See also Letter from M. Ann 
ranches, or commercial properties whose use was compatible with the mission of the park. In other cases, the private uses were undesirable, but the owners strongly wanted to remain and were able to obtain political support to prohibit acquisition. ${ }^{19}$ In still other cases, landowners convinced Congress to exclude their holdings from the park boundaries-so that while they were physically within, or nearly within, the park, legally they were outside it. ${ }^{20}$ These practices have created some striking anomalies. In the heart of Grand Canyon National Park, for example, only a few minutes walk from the El Tovar Hotel, which is the center of visitor activity, stands a uranium mine. ${ }^{21}$ Yosemite National Park contains a residential community near its southern boundary at Wawona.22 Numerous other such oddities exist, though their total acreage is not great. In the parks established before July, 1959,23 total inholdings amount to only 32,000 out of many millions of acres. ${ }^{24}$

As to lands outside park boundaries, the general practice was one of benevolent disinterest. If serious problems of incompatible use arose, Congress would enlarge the park boundary to include those lands. ${ }^{25}$ Conversely, lands within existing parks, coveted for private development, occasionally were excluded from the park boundaries. ${ }^{26}$

These practices led to a rather formalistic set of policies that still exists for "old parks"--those established before July, 1959.27 First, a

Belkov, Superintendent, Chickamauga and Chattanooga National Military Park, to author (Mar. 26,1980 ).

19. Superintendent Survey, supra note 5 (Olympic National Park (Feb. 15, 1980)).

20. See note 12 supra.

21. In 1962 the mine was acquired subject to a continued operation until 1987. The mine is presently not operational for economic reasons. National PaRk SERvice, U.S. Dep'T OF THE Interior, Grand Canyon National Park, Draft land acquisition Plan 2 (1979).

22. National Park Service, U.S. Dep't of the Interior, Yosemite National Park, DRAFT LAND ACQUiSition PLAN 9 (1979).

23. This is the cut-off date by which the Park Service distinguishes old from new parks; separate policies apply to each. Land Acquisition Policy 24,790.

24. Id.

25. J. ISE, supra note 18. Congress has begun to address the problems of adjacent lands more directly in regard to new parks, though it retains the traditional practice for old parks. See, e.g., 16 U.S.C. \$ 460ii-4(c)(1) (Supp. II 1978) (Chattahoochee River N.R.A.); NATIONAL ParK SerVice, U.S. Dep't of the InTerior, Statement for Management, Congaree Swamp NaTIONAL MONUMENT 6 (1979).

Congress, however, frequently resists such suggestions. At Custer Battlefield National Monument in Montana, for example, both the War (Defense) Department and " $t$ three or four NPS master plans dating back to 1940 have identified" a need to enlarge the present battlefield. But no action has been taken because there is no authority to condemn and private landowners are seeking six to ten times the appraised value in negotiation for sale. Letter from Superintendent Jamcs V. Court to the author, Ref. L14 (CUST) (Mar. 4, 1980); Superintendent Survey, supra note 5 (Custer Battlefield National Monument, (Mar. 4, 1980)).

26. See generally J. ISE, supra note 18.

27. The policies described in the following paragraphs are drawn from the Land Acquisition Policy 24,790. 
distinction is made between inholdings (lands inside the boundaries of a park, but not federally owned) and lands outside the boundaries. The current policy respecting inholdings is one of eventual acquisition (when and if there is a willing seller) on the theory that all land within the park boundary sooner or later should come under the control and management of the Park Service. ${ }^{28}$ As to land outside the boundaries, however, there is no such policy, nor is there any pohicy of federal control of those lands. Consequently, a tract of private land nearly surrounded by a park is-like all private land adjacent to a park-wholly outside the park's control. In general the physical boundaries of the park are therefore treated as "problem boundaries," i.e., as the appropriate natural boundaries of the area of the park's concern. Often, however, park boundaries are not coextensive with problem boundaries such as an entire watershed or the prospect of an historic battlefield.

A somewhat different policy exists for all parks established after July, 1959. For these "new parks," the general policy is one of prompt acquisition of all privately owned lands within park boundaries, as contrasted with the old park pohcy of eventual acquisition. Exceptions permit existing residents of new parks to retain their residences and a few acres of surrounding land for their hifetimes or a period of years, as long as they do not significantly change their present use of the land. The policy regarding lands outside new park boundaries is the same as the policy for old parks: Congress does not plan to acquire or control such lands.

Policy variations complicate matters further. In new parks that contain existimg communities, the policy of prompt acquisition is suspended as long as the community maintains restrictive zoning laws consistent with guidelines issued by the Secretary of the Interior. ${ }^{29}$ If the zoning is changed, or not enforced, the power of condemnation is reinstated and the land is acquired.

28. See, e.g., National Park Service, U.S. Dep'T of the INTERIor Sequoia and Kings Canyon National Parks Land acquisition Plan 2, 7 (1979). The desire of the Park Service to end all private ownership and acquire fee title, even where no incompatible use is threatened, has puzzled and angered many people. See, e.g., The Federal Drive to Acquire Private Lands, supra note 9. The Yosemite plan, for example, was modified under landowner pressure. See note 22 supra. Apparently, some Park Service officials view ultimate fee acquisition as a faithfuI response to congressional pohicy and National Park history. See SeQuoia AND KINGs Canyon National Parks Land AcQuisition Plan, supra at 2. Apparently, private landowners, howevcr modest their activities, are viewed as a continuing managerial nuisance within the parks. The failure to be more tolerant in this regard has earned the Park Service some strong opponents among owners of inholdings. The plan suggested in this Article would counsel greater tolerance for such imholders, and less tolerance for more threatening landowners.

29. Sax 242 n. 19. 
In a few of the very newest parks still another scheme applies. ${ }^{30}$ An inner core of park land functions much like any ordinary national park. Within the much larger surrounding area, the federal government subsidizes and promotes local, regional, or state land use regulation designed to protect the inner federal core. While there is no federal compulsion to adopt such regulations, there are strong financial incentives and the negative incentive of possible federal condernnation. At this time, it remams an open question whether the federal incentives will lead to adequate protective legislation by local or state authorities.

In sum, these various arrangements have resulted in the following situation. Except for a few of the newest parks, threats of incompatible development of private lands outside the parks go largely unattended. Park Service officials try to work with local governments to encourage the enactment of effective land use regulations, but their influence is purely advisory and often ignored. If threats of development on outside lands become imminent, Congress can and sometimes does extend park boundaries to acquire the threaterning land.

Within new parks, almost all private holdings have been or are being acquired. ${ }^{31}$ The land that has not been acquired is protected by local zoning laws that are kept in place by the threat of condemnation. The biggest problem in new parks is that acquisition funds are soinetimes not authorized promptly enough to prevent incompatible developinent of private tracts ${ }^{32}$ or to prevent a price escalation that eventually might deter Congress from completing the acquisition. In old parks, compatibly used inholdings are acquired only if the owner is willing to sell or if incompatible development is imminent. Though the total acreage of inholdmgs is small, much of that acreage is critically located, and its incompatible development could be highly detrimental to the parks.

This brief suminary of present policies may suggest that Congress has the problein of incompatible development well im hand. ${ }^{33}$ Unfortunately, this appearance is deceiving.

30. See note 5 supra.

31. Existing, compatible uses are ordinarily permitted to be reserved for a term. Land Acquisition Policy 24,793-95. In some places potential problems are more serious, as at Big Thicket and Big Cypress National Preserves, where Congress has permitted the retention of oil and gas interests. See 16 U.S.C.A. $\S \S 698 \mathrm{a}(\mathrm{a}), 698 \mathrm{f}$ (c) (West Supp. 1980); The Federal Drive to Acquire Private Lands, supra note 9, at 57. The Park Service has issued regulations to control the nature of developinent in such places. 36 C.F.R. $\$ \$ 9.30-.52$ (1979).

32. See note 15 supra.

33. I am unable to say how effectively even this stated policy is implemented. See Letter, supra note 15 , that states: 


\section{B. The Lassen Example}

The Lassen Volcanic National Park in California ${ }^{34}$ illustrates the problem of incompatible development. In 1916, when the park was established, ${ }^{35}$ one section of forested land (the Andrus Tract) existed as a private inholding just withm the park's southern boundary. Because the land was not being put to any incompatible use (indeed, for many years it was apparently not put to any private use at all), it was never acquired. Around 1960, however, the tract was leased to Phillips Petroleum Company for geothermal development, and the Park Service began efforts to acquire it voluntarily through an exchange for other federal lands outside the park boundaries. At that time, funds for purchase were difficult to obtain, and a land exchange was undoubtedly the most promising strategy. In any event, no exchange satisfactory to the landowners could be arranged. In 1962, Phillips drilled an exploratory well to 1,285 feet, but found no geothernual resources; the well was capped and left in a condition to be re-entered at a later date.

Though its files are not very revealing about the 1962 incident, the Park Service likely viewed the exploratory drilling as insufficiently damagmg to cause alarm; because no otler activity was imminent, the Service took no action. Fifteen years later, in 1977, geothernual development had become more attractive and Phillips returned. County zoning law required Phillips to obtain a drilling permit; the Park Service participated in the hearmgs on the permit, but took no strong action. It inerely observed that the federal government might have the last word on whetler drilling would be permitted. No doubt park

On a recent visit to Grand Teton National Park, I . . . was surprised and concerned to find that many of the privately-owned lands in the park have been subjected to development in recent years. My understanding has been that . . . any initiation of a change in the use of these lands has triggered acquisition of the property. This has obviously not been the case at Grand Teton National Park.

See also Hearings 272. A report entitled Changes in Land Usage Over the Past Five Years, $1972-$ 77 , details the developments, mostly residential, that took place on National Park inholdings during the five years. It reveals substantial development of a number of parks, especially Glacier, Grand Teton, Olympic, and Yoseinite. The report is enclosure II to the National Park Service Director's first quarterly report to Congress on declarations of taking for July-Sept., 1977 (unpublished, on file with author).

34. The data on the Lassen case are taken from the voluminous National Park Service files in both the Washington office and the Park Headquarters, on the so-called Andrus Tract near the park's southern boundary. The unpublished material consists mostly of correspondence and interoffice memoranda. The materials are on file with the author as well as with the Park Service. Citations to each memo and letter are omitted. A brief but useful summary of the controversy appears in a letter from Robert L. Herbst, Assistant Secretary of the Interior, to Phillip Burton, Chairman of the House Subcommittee on National Parks and Insular Affairs, No. L1425(640), ES-57309 (Nov. 11, 1979).

35. See 16 U.S.C. $\$ 201$ (1976). 
officials would have preferred a denial of the permit, but as they have no authority in matters of local zoning, they merely let their uneasiness be noted in the commumity.

The Park Service then sought standby authority from Congress to condemn the tract. Because congressional committee approval is required for every condemnation, park officials wanted to be ready with a declaration of taking before Phillips began drilling. Unfortunately, 1978 was a time of general controversy over Park Service land acquisitions, ${ }^{36}$ and Congress informally deferred the request for condeinnation authority. Meanwhile, Phillips proceeded with its work. By August, it had built a road into the well site area and cleared land for a drill rig and other equipment.

In September, Park Service officials determined that the damage to be feared - surface damage-had already occurred and that the drilling itself would not upset underground thermal conditions in the park. A study by the United States Geological Survey bolstered this conclusion. Officials also beheved that test drilling would provide useful imformation about the value of the tract in the event condemnation did go forward. In October, 1978, Phillips drilled another exploratory well to 4,000 feet, capped the well, removed its equipment, and cleaned the site. The condenination plan was again put in abeyance.

One year later, in September, 1979, Phillips resumed activity at the site. This time it dug a trench two hundred feet long, eight to ten feet deep, and twenty feet wide, and brought heavy equipinent on the site. With extensive surface damage already done, and with the immediate prospect of a good deal more mining, the Park Service again sought and this time received condenmation authority. At the time of this writing, a declaration of taking has been filed, and all that remains is ascertainment of the amount of money to which the landowners are entitled. ${ }^{37}$

It would be easy, in hindsight, to portray the Lassen case as one of governmental slow-footedness. The important question is not, however, whether the response to that particular event was insufficient-for variants of the Lassen situation arise routinely in and near the parksbut why policies exist that defer condemnation until it is so late. Why did the government not obtain binding protection against miming in 1976 or 1962 , or even years earlier? The conventional answer is that

36. Hearings 192-94, 263-367. See also National Park Service, U.S. Dep't of the Interior, News Release, NPS Announces New Public/Private Sector Effort at Yosemite National Park (Nov. 29, 1979).

37. See United States v. 566.08 acres of Land, No. 80-305-PCW (E.D. Cal., Apr. 21, 1980). 
condemnation of all or some part of the owner's rights would have been required, and that condemnation is an extreme form of government action to be used as little as possible. But this conventional response does not explain what happened at Lassen; Congress did condemn, and the question is what it gained by waitmg.

In some instances Congress is understandably reluctant to condemn at all, as, for example, when a long-standing resident is living on land within the park and domg nothing to interfere with park nanagement. Congress may also want to defer condemnation while waiting for an existimg resident's lifetime to pass. Neitler situation was present at Lassen. Congress could have acquired development rights there (for example, the right to cut timber or to mine) many years earlier without dislocating residents or disadvantaging them economically. Nor was there any reason to defer to the landowners out of respect for a community's right to determine its own destmy-as the Congress miglit do when a neighboring Indian community uses its lands in a manner incompatible with park objectives.

Several reasons may explain the delay. Perhaps Congress believes that a landowner is entitled to reap the full economic benefit that his land is capable of producing. Because, as a result of acquisition, he cannot reap that benefit by mining or other development, he could be allowed to take it in the form of condemnation payinents at the highest use value the land may attain. Under this theory, it would be appropriate to let the owner hold the land for its development value until that value had reaclied a peak, and then, just before any damaging action took place, to condemn the land and pay the owner the full market value. It is difficult to believe that Congress would adopt such a policy. Although there is nuch to be said in favor of leaving a resident in his home (a situation I shall discuss below), compassion does not suggest that an investor should be left with his mvestment. Surely no primciple of law or fairness would have been violated if the owners of the Lassen tract had been subjected to eminent domain in 1962 and at that time given the full current market value of their land. Had that been done, not only would the park have been spared the threat (and as it turned out, the reahity) of damage, but the real cost to the government would have been substantially less than it will be in 1980 . The owners would have been free to invest their $\$ 500,000$ (the estimated 1962 value of the tract) anywhere else they cliose for the highest return they could obtain. They would simply have been prevented from investing it in land whose development threatened a National Park.

A more likely explanation for the delayed purchase is that Congress beheves deferring acquisition serves the taxpayers' economic self 
interest. If, for example, there were a hundred tracts like that in Lassen, but in fact only two or three would ever be exploited, it might well be most economical for Congress to wait until exploitation occurred, and then condemn only those two or three. Even if the price for those few tracts at the time of condemnation were high, it would still be cheaper to buy thein "late and high," than to condemn development rights im the entire hundred parcels "early and low."

Whether deferring acquisition minimizes costs turns on two factual questions: (1) How much private land that might be incompatibly developed, and would be condemned if it were so developed, will in fact be mcompatibly developed? (2) What is the relationship between the rise in value of these lands and the mterest rate on money? The second question is perhaps more important. If, for example, the value of money were ten percent per year, and private lands suitable for development were appreciatimg at the rate of ten percent a year, there would obviously be no economic gam im acquiring those lands before the threat of development became imininent. Because, im such a case, there is always some possibility that a tract will never be developed, it appears that the government cannot lose and will sometimes gam by deferring purchase until imcompatible development is imıment.

Of course, we know exactly what the rate of interest has been over the years. We do not know witli any precision the rate at which the value of private landholdings like that at Lassen have been rising. We do have, lowever, some estimates of the rate. A recent survey sent to all National Park System superintendents asked them to identify lands within and outside park boundaries threatened by incompatible development. ${ }^{38}$ The survey sought to identify those lands that would be recominended for condemnation if certam incompatible developments were begun. One question asked for an estimate of the comparative cost of acquiring those lands today with the cost of acquiring them five years earlier, ten years earlier, and at the time the park had first been established. The goal was to discover whether Congress was im fact saving money by deferring acquisition of such lands.

The answers-admittedly only rough estimates ${ }^{39}$-are little short of astonishing. Ninety percent of the superintendents reported that the

38. Superintendent Survey, supra note 5.

39. In a few instances we do have fairly reliable data that confirin the estimates from other parks. The Superintendent Survey from Delaware Water Gap National Recreation Area, for example, produced actual acquisition figures for acreage acquired between 1970 and 1980. The National Park Service estimates that average values of inholdings rose from $\$ 1,397$ per acre to $\$ 2,950$ per acre from June, 1972 to September, 1976. Changes in Land Usage Over the Past Five Years, supra note 33. 
lands in question had at least doubled in value over the last five years and had at least tripled in value over the last ten. Eighty-five percent estimated that land values had at least quintupled and fifty percent said they had risen ten-fold or inore over ten years. For old parks, values reportedly had increased from fifty- to one-hundred-fold since the date of the park's establishment; in a few cases (doubtless with soine hyperbole) superintendents even reported a thousand-fold imcrease.

At the actual rates of interest during the last five years, land that had done no more than keep pace with the cost of money would have risen less than 1.5 times its value five years earkier. ${ }^{40}$ As one goes back in time ten or inore years, when interest rates were markedly lower, the differential between the rise in land values and the increase in the value of inoney becoines even more drainatic. ${ }^{41}$ Of course, these data merely confirm what is widely known: that land has appreciated faster than inoney invested at current rates of return.

It is nonetheless possible that Congress is saving money by deferring condemnation if much of the private land that could be incoinpatibly developed will not in fact be developed. Of all the land that park officials beheve might be developed for incompatible use, how inuch will in fact be so developed, and how inuch of that will in fact be acquired? A definitive answer to these questions is difficult to obtain, but again, the survey evidence is revealing. The superintendents' responses to the survey showed that over seventy percent of the landowners were not willing to sell, principally because they were holding their lands for developmental growth prospects-for residential subdivision, for mining or timber harvesting, or for commercial uses such as resorts. ${ }^{42}$ In

40. U.S. Dep't of Commerce, Bureau of the Census, Statistical Abstract of the United States 542, 495 (1980); Historical Statistics of THe United States: Colonial Times to 1970, H.R. Doc. No. 78, 93rd Cong., Ist Sess. 1003 (1973).

41. The following interest rates are the unweighted average for all outstanding bonds neither due nor callable in less than 10 years. The figures are based on daily closing bid prices.

\begin{tabular}{ll|ll}
$\frac{\text { Year }}{1978}$ & $\frac{\text { Rate }}{7.89}$ & $\frac{\text { Year }}{1968}$ & $\frac{\text { Rate }}{5.25}$ \\
1977 & 7.06 & 1967 & 4.85 \\
1976 & 6.78 & 1966 & 4.66 \\
1975 & 6.98 & 1965 & 4.21 \\
1974 & 6.99 & 1964 & 4.15 \\
1973 & 6.30 & 1963 & 4.00 \\
1972 & 5.63 & 1962 & 3.95 \\
1971 & 5.74 & 1961 & 3.90 \\
1970 & 6.59 & 1960 & 4.01 \\
1969 & 5.10 & 1959 & 4.07 \\
& & 1958 & 3.43
\end{tabular}

U.S. Dep't of Commerce, Bureau of the Census, supra note 40.

42. See, e.g., Letter froin Thomas L. Hartman, Superintendent, Cumberland Gap National 
short, the owners believed in nearly three out of four cases, that their lands were likely enougli to be developed to be worth holding for their rising development values.

By indulging in a few assumptions, one can roughly estimate the economic consequences of a policy of deferring acquisition until development is imminent. If the average deferral from the first opportunity for acquisition until actual acquisition is ten years, the average rate of interest during that ten years is ten percent per year, ${ }^{43}$ and one relies on the park superintendents' estimates of land appreciation, ${ }^{44}$ then the cost

Historical Park, to the author, Ref. No. L 1415 (Mar. 7, 1980), following up information given in Superintendent Survey, supra note 5:

[T] he acquisition of the 6,000 acres in Tract 3 is the park's highest priority. . . . Unfortunately, most of the ten landowners in Tract 3 are at present unwilling to sell, for a variety of reasons including the rapidly increasing value of coal reserves and the desire to hold the property as an investment.

43. In fact, the average deferral is probably more than 10 years; at Lassen it was nearly 20 at the least. Average interest rates during the 1970 s were in fact less that $10 \%$ per year. Each of these assumptions is therefore conservative; the actual prices paid upon acquisition undoubtedly were higher than the "early acquisition" price I have estimated.

44. Excluding those parks where respondents did not anticipate any prospect of incompatible developinent, or where the information was incomplete (34.7\%), the estimates of land price escalation for threatened lands, both within and outside park boundaries, by the remaining $65.3 \%$ of respondents, were as follows:

ESTIMATES OF LAND PRICE ESCALATION OF THREATENED LANDS

\begin{tabular}{|c|c|c|c|c|}
\hline \multirow[b]{2}{*}{$\begin{array}{l}\text { Increase in } \\
\text { Land Values } \\
\text { as a Multiple }\end{array}$} & \multicolumn{2}{|c|}{ Over the Last 5 Years } & \multicolumn{2}{|c|}{ Over the Last 10 Years } \\
\hline & $\begin{array}{l}\text { Nuinber of } \\
\text { responses }\end{array}$ & $\begin{array}{c}\% \text { of } \\
\text { responses }\end{array}$ & $\begin{array}{l}\text { Number of } \\
\text { responses }\end{array}$ & $\begin{array}{c}\% \text { of } \\
\text { responses }\end{array}$ \\
\hline None & 3 & 2.8 & & \\
\hline 1.5 & 8 & 7.4 & & \\
\hline 2 & 42 & 38.9 & 8 & 7.7 \\
\hline 3 & 16 & 14.8 & 8 & 7.7 \\
\hline 4 & 3 & 2.8 & 8 & 7.7 \\
\hline 5 & 14 & 13.0 & 23 & 22.1 \\
\hline 7 & & & 1 & 1.0 \\
\hline 8 & 1 & .9 & 5 & 4.8 \\
\hline 10 & 14. & 13.0 & 28 & 26.9 \\
\hline 15 & & & 1 & 1.0 \\
\hline 20 & 2 & 1.9 & 10 & 9.6 \\
\hline 25 & 3 & 2.8 & 1 & 1.0 \\
\hline 30 & 1 & .9 & & \\
\hline 40 & & & 2 & 1.9 \\
\hline
\end{tabular}


of ultimate acquisition to the government is almost six times the acquisition cost ten years earlier. ${ }^{45}$

This calculation assumes, of course, that all the land appropriate for development is in fact incompatibly developed and is ultimately acquired. Even if only three-fourths of the land is so developed (the best estimate we can make), ${ }^{46}$ the cost would still be four to five times as great. Indeed, the costs would be equal only if as little as one-sixth of all the land identified by superintendents as potentially threatened with development in the foreseeable future is actually developed.

The above estimates, rough as they are, nonetheless strongly imply that a policy of deferring acquisition is economically unsound. If the government acquired the development rights on all the lands that superintendents identified as being subject to incompatible development, and only one-lialf or one-third of those lands were ever actually

ESTIMATES OF LAND PRICE ESCALATION (Continued)

\begin{tabular}{lccccc}
\hline & \multicolumn{2}{c}{ Over the Last 5 Years } & & \multicolumn{2}{c}{ Over the Last 10 Years } \\
\cline { 2 - 6 } $\begin{array}{l}\text { lncrease in } \\
\text { Land Values } \\
\text { as a Multiple }\end{array}$ & $\begin{array}{c}\text { Number of } \\
\text { responses }\end{array}$ & $\begin{array}{c}\% \text { of } \\
\text { responses }\end{array}$ & $\begin{array}{c}\text { Number of } \\
\text { responses }\end{array}$ & $\begin{array}{c}\% \text { of } \\
\text { responses }\end{array}$ \\
\hline 50 & 1 & .9 & 3 & 2.9 \\
\hline 60 & & & 1 & 1.0 \\
\hline 100 & 108 & $100.1 \%$ & 104 & $100.1 \%$
\end{tabular}

Note: Since not all parks reported usable information, I have data for different numbers of parks for the five and ten year periods. The huge rises at some parks (e.g., 100 fold increase), come largely from places where superintendents noted that mineral values have taken a spectacular rise in recent years.

45. Assume that the 104 parks reporting usable data for the 10 year period (see note 44 supra) each contained one tract of land, worth $\$ 100$ ten years ago and rising in value at the reported rate. The actual cost of having acquired those 104 tracts 10 years ago would be $\$ 100$ plus the lost interest for 10 years at $10 \%$ per year, or $\$ 257$ per tract, for a total of $\$ 26,728$.

Accepting as accurate the reported rise in actual value as noted in note 44 supra, the actual cost would be $\$ 154,400$ (the cost of each of the 104 hypothetical tracts at the reported increinent in value for each: for example, 8 tracts doubled over 10 years for a total value of $\$ 1,600: 23$ tracts quintupled, for $\$ 11,500$, and so on). Divide $\$ 154,400$ by $\$ 26,214$ to give 5.89 or nearly 6 .

The calculation depends on the following assumptions: (1) there is the same amount of threatening land in or adjacent to each park; (2) the government will ultimately buy as much land rising rapidly in value as land rising slowly; and (3) approximately the same acreage of land will double in value as will triple, quadruple, etc.

46. See text accompanying note 42 supra. Because nore than $70 \%$ of the landowners were holding their land for growth of development values, it is reasonable to assume that they think the likelihood of development is substantial. I have used the figure $75 \%$ for purposes of simplifying the cost comparison. 
developed, the government would still realize a considerable savings by buying the rights to the lands "early and low." 47

Unfortunately, the failure of Congress to distinguish between capital expenses such as land acquisition, and ordinary annual operating expenses, makes a policy of early purchase difficult to adopt in practice. Congressional budgeting practices treat every dollar not spent this year as a dollar saved. A dollar not spent on welfare or secretarial salaries is treated the same as a dollar deferred for spending until next year or ten years hence. Current practices conceal the fact that a dollar not spent this year on land acquisition will turn up as six dollars to be spent in ten years-which is no saving. Conversely, a dollar not spent on salary this year is genuinely a dollar saved.

Note that nothing said here suggests that Congress should acquire any particular quantum of development rights, or that it should restrain private development more than it presently does. The example only suggests that for lands like the tract at Lassen-where certain potential uses can be identified as incompatible, and where acquisition is appropriate to prevent those uses-there is no economic reason to defer acquisition until the threat of development is imminent. Indeed, a costminimizing policy clearly favors the earliest possible acquisition.

One furtler argument made in favor of deferred acquisition is that the inere threat of future condemnation will deter landowners from making incompatible uses. If such a strategy succeeds, the government achieves the result it wants without any outlay of money. While Congress generally has been extremely sensitive to the interests of landowners, a scheme to deter development by the threat of eminent domain is extremely harsh to those owners. To the extent that it succeeds, it effectively imposes federal zoning of the most informal and uncontrollable kind. The landowner is prevented from reaping his development opportumities without any compensation and without any procedural protections.

Indeed, some years ago a landowner challenged this policy, asserting that a threat to condemn was itself a taking of his property. ${ }^{48}$ The

47. Obviously an economic strategy of early acquisition only makes sense if one forecasts that land will outperform money invested at the current interest rate. If such forecasts cannot be made, it would no longer make economic sense to have a policy of early acquisition. At least over the last few decades it is clear that a policy of early acquisition would have minimized costs to the government.

48. Halpert v. Udall, 231 F. Supp. 574 (S.D. Fla. 1964), affd, 379 U.S. 645 (1965).

The prospect of condemnation seems to have a wide range of effects on land values, subject to no clearly consistent pattern. The Superintendent Survey, supra note 5, from Chattahoochee River National Recreation Area reports: "A rather strange situation here. The NPS land acquisition [bailed] out some bankrnpt developers. Some adjoining land ownerships fear a public park, so values are depressed. However, some are advertising park as a benefit and charging more when they sell." The land acquisition file on Big Thicket National Preserve, from the National Park 
presence of the threat, he asserted, destroyed the prospects for development and hence the market for purchasers of his land. The court held that the owner would get full compensation when he did decide to develop his land, and that the government was free to exercise eminent domain when it chose and nothing had yet been taken from the landowner. Although the court rejeeted the legal claim, the outcome of the case does not dispose of the problem of fairness to the landowner. To the extent that the landowner wants to remain on his land, the prospect of eviction can induce him to cleave to the line set by the government and thus to yield up all his development opportunities. ${ }^{49}$

Because the government may only need an easement or covenant against developinent and not the landowner's underlying fee, the threat of a taking in fee penalizes development that the government disfavors. The threat is likely to be most effective against the least sophisticated and economically least powerful landowners. The mere prospect of a condemnation action in court, involving lawyers and expenses and the risk of an inadequate award, doubtless terrifies some small proprietors. Moreover, a small owner may not be able to make the prospect of development credible if condemnation is a lurkmg threat. He may not, for example, be able to obtain financing. Such problems do not exist for owners like Phillips Petroleum at Lassen, who can easily find financing for development and who do not fear courts and lawyers. The condemnation-threat policy may thus have its greatest impact on the very owners who are the least able to protect themselves.

Because the policy can have such differential impacts, and because some landowners, like Phillips, are sophisticated, the threat of condemnation often does not diminish land values. Most parks report that developinent values have continued to rise more rapidly than the rate of inflation, suggesting that development value for incompatible uses is still being refleeted in the market price of these lands. Survey evidence

Service Land Acquisition Division in Washington, contains numerous letters from landowners complaining that the prospect of acquisition has made their land unmarketable. Of course these are instances in which land acquisition is going forward, not situations where the government is trying to prevent development by the threat of future condemnation. But they suggest, at least, that some landowners do not believe they will profit from a condemnation. For reports of land values declining under the threat of condemnation, see the Superintendent Survey, supra note 5 , for Pictured Rocks and Sleeping Bear Dunes National Lakeshores.

49. It is not clear (at least to this author) from the current land acquisition policy whether a landowner whose property is condemned because he is about to use it in a fashion incompatible with Park Service objectives will get the benefit of the compassionate reservation of use and occupancy policy. Land Acquisition Policy 24,790. If he will, then the threat to condemn will surely be less of a deterrent to incompatible development, since the owner will have nothing to lose by undertaking development. See discussion in text immediately following note 50 infra. 
reveals that development value commonly accounts for eighty to ninety percent of total value..$^{50}$

Why is this the case? In some instances owners no doubt believe that despite a policy opposing such development, they will im fact be able to get away with it. Landowners realize that the government will act so slowly in moving toward condemnation that it will be presented with a fait accompli, and ultimately will tolerate rather than condemn the mcompatible use. Otlier landowners are playing an investor's game, recognizing that plans for incompatible use will hikely lead to condemnation, but that condemnation awards will be large, justifying their holding the land as long as possible.

Sophisticated landowners doubtless are adopting the above strategies, for they can hardly lose. If the government decides to tolerate the development, the landowners succeed; if the landowners plan for development and are tliwarted by condemnation, but receive the full development value of their land in a condemnation proceeding, they still succeed. $^{51}$ Indeed, under the present policy the landowner has the advantage of deciding exactly when to sell out, and can choose the moment when lie thinks his land values are at their peak. At that point he can offer to sell to the government. If he can negotiate a mutually satisfactory price, he sells out at the ideal time from his point of view. If he cannot reacli an initial agreeinent on price, he can threaten to put the land to an incoinpatible use and force the government's hand. Because the owner of condemned property is entitled to his land's full present development value, he can then sell out-by means of the condemnation-at his top price. Ironically, the deferred acquisition policy actually generates pressure to develop land-at least on the part of the knowing landowner-for only by creating a threat of incoinpatible development is sucl a landowner likely to receive the maximum price for his land.

The Lassen case deinonstrates this plienoinenon. The Park Service liad inade clear since 1962 its intent to condemn the land if geothermal development went forward, yet that threat did nothing to discourage the oil company lessee or the owners. They neither ceased their development activity nor responded to offers to buy or to exchange their land for other tracts. Why should they have responded? ${ }^{52}$

50. Altogether, $55 \%$ of respondents reported that development rights accounted for $90 \%$ or more of the total market value. Only $20 \%$ of respondents said development rights accounted for less than $75 \%$ of total value. Superintendent Survey, supra note 5.

51. The worst situation occurs when incompatible development is permitted to proceed and the developed land is then condemned at a very high price. This has occurred in a number of instances. Hearings 310-19.

52. The Park Service's opportunity purchase program (acquiring lands by negotiated purchase from willing sellers) did produce a number of sales, Hearings 279-80, but many other 
Their land (according to park officials) had increased in value ten-fold in ten years; they would have been foolish to sell out in 1962. Moreover, Phillips very inuch wanted to explore the land and its exploration was producing useful information about geothermal resources on other nearby land outside the park boundaries. It was entirely in their economic interest to see if the government's threats to condemn were inere bluffs.

In these respects the Lassen case exemplifies a misdirected policy, which achieved neither cost minimization nor fair dealing. But Lassen involved a pure investment owner outside of any community and without any personal stake (e.g., a residence) on the land in question. Many situations are more complicated: owners threaten incompatible use of private land where individuals reside, and where there is an established commumity with interests of its own. The problem is illustrated by the situation at Grand Teton National Park. ${ }^{53}$

\section{The Grant Teton Example.}

Most of the land in Teton County, Wyoming is federally owned. The 50,000 acres of private holdings are surrounded on the north by Grant Teton National Park and on the other three sides by national forest land and the National Elk Refuge. Most of the private land is in a large open valley known as Jackson Hole where there are several commumities, the largest of which is the town of Jackson itself. Jackson Hole had long been primarily a ranching area and Jackson a sleepy mountain town. The traditional agricultural community was not only compatible with the park, but was a desired private neighbor. Western ranching provided an historically attractive foreground and setting for the park, though the Park Service had no interest in managing or using these lands.

Durmg the past decade, however, the situation began to change. The growth of alpine skiing and the development of a ski resort on

important lands (like Lassen's Andrus Tract) were not acquired. The Service probably acquired primarily those lands whose values had already peaked or that were already developed to the himits of the owner's ability.

53. The situation at Grand Teton is spelled out in considerable detail in Hearings, supra note 4, and in Boundary Study, supra note 12. See also National Park Service, U.S. Dep't of the Interior, Jackson Hole Land-Use Study, Grand Teton National Park (1976); Hocker, Jackson Hole: Are We Loving It to Death?, SiERRA, July/Aug. 1979, at 14; Leydet, Jackson Hole: Good-bye to the Old Days?, 150 NATIONAL Geographic 768 (1976).

The proposed bill to create a Jackson Hole Scenic Area and to acquire, with federal funds, development rights in Jackson Hole, is H.R. 9135, 95th Cong., 1st Sess. (1977). See also 123 CONG. Rec. S16,035 (1977). The description of the Jackson Hole situation in the text is taken from these sources. 
National Forest land adjacent to the park were important factors, as was the general recreational boom that brought more and more visitors to the Jackson Hole area. The kind of urbanization that has become familiar near ski resorts throughout the mountain West occurred in Jackson Hole. Land values began to rise rapidly. Ranches were sold and subdivided for hotels and vacation homes. The town of Jackson grew; commercial enterprises started to line the entrance roads, heavy traffic and crowds appeared, and homes sprang up on rises visible from the park. Development was also threatening the wintering range of the resident elk herd. Park Service officials, as well as many citizens of Jackson County, agreed that a continuation of such development would be undesirable and incompatible with the mission of the park. As in many rural communities, there was little land use regulation in Jackson County-certamly too hittle to control the burgeoning growth. ${ }^{54}$

Because the Jackson Hole lands were never within park boundaries, the Park Service had not considered acquiring them.ss Not until development was well underway did restraint on mcompatible uses become a lively issue. This case thus gives us the opportunity to consider developmental controls as an issue where land use values have already risen substantially, perhaps even approaching their maximum levels. Present estimates are that the ranch land threatened with development is worth between $\$ 4,000$ and $\$ 9,000$ per acre, of which only about $\$ 500$ per acre reflects its value for ranching. Acquisition of the land in question could thus cost from $\$ 200$ million to $\$ 450$ million; if acquisition were limited to development rights, the cost would only be reduced by about $\$ 25$ million. ${ }^{56}$

What differentiates the Jackson Hole case from the Lassen case is the presence of an established community with residents whose interests are not merely in investment profit. Even if it were willing to do

54. See Teton County Comprehensive Plan and Implementation Program (Dec. 6, 1977) (unpublished, on file with the author); Amendment to the Comprehensive Plan, Teton County, Wyoming (Nov. 20, 1979) (unpublished, on file with the author). Even modest land use regulation generated strong local opposition, and proposals for weakening the existing laws became an electoral issue in Teton County.

55. The bitterness stemming from acquisitions that John D. Rockefeller made in the 1920s and then turned over to the federal government was another reason the Service had not acquired the land. See J. ISE, supra note 18, at 492-508; Righter, The Brief, Hectic Life of Jackson Hrole National Monument, THE AMERICAN West Nov./Dec. 1976, at 30.

56. In such circumstances, the government understandably turns its thinking to zoning rather than acquisition as a means of constraining development. Zoning raises a new and troublesome question of what principles ought to guide the decision to acquire and compensate rather than to induce local governments to impose uncompensated zoning. See text accompanying notes 65-66 infra. 
so, the government would impose a considerable hardship on the community by simply condemning the land for use as a park. The government could, however, acquire a right prohibiting incompatible developments, leaving existing residents and existmg compatible activities such as ranching in place. A procedure similar in effect is used at new parks, where lands within park boundaries are acquired with a hfetime or longterm right in existing coinpatible uses reserved to the former owners. Why has this technique not been used at Jackson Hole? At a purely descriptive level, the answer is that Congress has not generally turned its attention to the threat of incompatible uses outside the parks. Another answer is that Congress has chosen, for reasons that are by no means clear, to be more tolerant and more patient with developmental threats at old parks than it has at new ones. The cost at Jackson Hole-several hundred million dollars-is also a factor, raising the question whether zoning, rather than acquisition, is the appropriate solution. In addition, Congress has not yet clearly distinguished between two quite dissimilar interests: the desire of existing residents to remain, and the desire of those residents to hold an investinent interest in their land.

There are other, inore comphicated, reasons. Let us imagine the case of a resident rancher who owns 160 acres in Jackson Hole. Assume that the ranch has a value of $\$ 500$ per acre for ranching, and an additional value of $\$ 4,500$ per acre for its development potential. The total value of the land is $\$ 800,000$, a considerable sum. In many cases, an agricultural landowner with such an estate-though it seems great to most of us- hives rather modestly. The estate is not producing the same income as an $\$ 800,000$ investment in stocks and bonds. Rather, it is producing the ranching income of an estate whose use value is only one-tenth that amount (160 acres times $\$ 500$ per acre).

According to officials at Grand Teton National Park, such land has roughly doubled in value in the last five years, and has quadrupled in value in the last ten years. ${ }^{57}$ The rancher's estate is growing at the rate of approximately eighteen percent per year. If the owner beheves that a similar rate of growth is likely to continue for some time, he would be foohsh to sell out. 58 In this respect his situation is like that of the oil company at Lassen. Insofar as he is not a professional investor, however, there is a difference: he is less likely to be able to find an alternative investment of equal promise. In that respect, government

57. Superintendent Survey, supra note 5.

58. Recent interest rates do not make $18 \%$ a year seem a large increment. In light of interest rates during the previous decade, however, it was a fine investment return indeed. 
acquisition of his development rights may well result in a real future economic loss to him.

There is another reason ranchers in Jackson Hole want to retain their land for its investment value. They believe that the cattle business is in a state of long-term decline. If ranching declines, the future opportunity to sell off a few pieces of land for subdivision could be the only way for ranchers to secure their economic future. Such landowners see themselves not as speculators with a fungible capital investment, but as people trying to hold on to their future in the community.

Syinpathy for the landowner in such a situation is natural, but yielding to sympathy ensures that urbanization and land subdivision will go forward, and that Jackson Hole will develop in ways harmful to the surrounding federal lands. Of course it is for Congress to decide whether it wishes to protect the park from such urbanization, or to tolerate urbanization in deference to the imterests of the landowners; no one can say which decision is indisputably right. ${ }^{59}$ Yet clearly it is wrong for Congress to delay some form of decisive action. If Congress permits the landowners to hold their property for future sale and subdivision, investors will buy the land, push up prices, and resist both local land use controls and "premature" federal acquisition. ${ }^{60}$ The longer Congress waits, the inore expectations it will disappoint, the higher the price it will ultimately pay, and the greater the likelihood that its policy for the area will be distorted by the high cost of acquisition.

It is one thing to let growth go forward if the growth and developInent itself occurs and brings some benefit to the society. But to let developinent occur, only to pay the landowners ultimately for the loss of phantom growth (the nonmining at Lassen or the nonurbanization at Jackson Hole) seems utterly unfruitful. Yet that is precisely what happens when the government delays, or remains equivocal about future

59. By failing to focus systematically on the consequences of adjacent development, and by not seeking to divert certain kinds of development away from parklands, the Park Service has subjected the long-term future of the park system as a whole to significant changes. See Letter from Robert E. Benton, Superintendent, Colorado National Monument, to the author, Ref. No. K14 (Mar. 3, 1980):

With the accelerated population growth of the Grand Junction-Fruita area one of the more popular sites is immediately adjacent to our boundary. To a subdivider this provides an excellent sales opportunity since those lots that border on the monument give in essence to the buyer a totally undisturbed back yard of many acres. We are finding that about 12 miles of our boundary is in subdivisions, either currently or planned. ...

... We often think that Colorado National Monument is rapidly changing from a natural national monument to an urban park area serving the adjacent community.

For a discussion of the significance of such transformations to the unission of the National Parks, see J. Sax, Mountains Without HandRails (1980).

60. Evidence of this proposition can be found in Draft Land Acquisition Plan, Grand Teton National Park, 4 (unpublished rough draft), which lists, among compatible uses for unimproved property, "Hold for speculation." 
growth on land in or near the parks. Rather than giving the owners the money value of their developinent rights at some early point, leaving them to re-invest elsewhere at the best rate they can find, the government leaves them with the development value of their land and then prevents the development from taking place. This is truly a misguided policy.

\section{Proposed Solutions}

Everything thus far suggests that the government routinely should buy development rights from landowners. There is, however, another possibility. Incompatible development should be regulated by federally encouraged local zoning, without any compensation, rather than by purchase or condemnation. As noted earlier, ${ }^{61}$ Congress appears to have adopted this approach in some places. In certain new areas, such as the Santa Monica Mountains and the New Jersey Pinelands, Congress does not buy private lands, but rather seeks to encourage local and state zoming by providing planning funds. ${ }^{62}$ In other places, it seeks to induce local zoning by threatening landowners with condemnation, giving them the choice of regulating theinselves as the government wishes or being condemned and removed from their lands. ${ }^{63} \mathrm{At}$ the same time, Congress has before it legislation concerning Jackson Hole that, if enacted, would commit Congress to purchase developinent rights at a cost of several hundred million dollars. ${ }^{64}$ Which is the proper solution? ${ }^{65}$

61. See text accompanying notes 29-30 supra.

62. See note 5 supra.

63. See note 5 supra.

64. H.R. 9135 , supra note 53.

65. Even where local zoning is properly enacted, developmental pressures are not always terminated. When demand for land is high, as we have seen repeatedly in the urban zoning context, pressures for variances and rezonings can be great, and the whole zoning plan-however well drafted-can collapse. While it is always free to condemn lands if local zoning fails to work, the federal government, in such circumstances, faces the problem of condemning at the very moment when prices are at their peak. An undue reliance on zoning could well be a delusion and useful only prior to the time that the demand for development sharply rises. Park Service officials, sometimes (but not always, see Superintendent Survey, supra note 5 (Valley Forge National Historical Park)) seem unaware of the fragility of zoning, perhaps because zoning is a relatively new technique for many of them.

One possibility is to wait for local zoning to be enacted and then to acquire development rights; once development potential is restricted by zoning, the purchase price of such rights, of course, falls substantially. There is always the risk that such a technique would be viewed by a court as illegal pre-condernnation down-zoning, see United States v. 45.28 Acres of Land, More or Less, 483 F. Supp. 1099 (D. Mass. 1979). If the government does not condemn the whole fee, however, such a protective strategy might well be successful at very little cost. 
The problem arises because the presence of potential fcderal acquisition distorts the evolution of ordimary local or state land use regulation. Many communities are willing to impose some land use regulation on themselves by way of local zoning. They have their own interest in regulating growth, and that interest will overlap-at least to some extent-the imterest of the federal government in controlling developinents incompatible with parks. Local governments in the communities where parks are established, however, ordinarily are satisfied with fewer restrictions than the Park Service wants, because preservation is not their mission. The federal government cannot, therefore, rely solely on what the local community is willing to do by way of conventional uncompensated zoning.

Moreover, once the local community perceives the prospect of acquisition, with full compensation by the federal government, it may be deterred from imposing even the degree of zoning that it wants to impose and that its citizens would tolerate. Why should the community restrict itself, absorbing the economic loss of self-regulation, when it can wait for Congress, because of congressional concern for the park, to bail the community out? This is precisely the citizens' situation in Jackson Hole. At the same time, Congress asks itself why the taxpayers should pay for what the community ought to impose on itself by way of uncompensated zoning. Surely, this is one reason that Congress has yet to enact a Jackson Hole Scenic Area bill, ${ }^{66}$ under which the fcderal taxpayers would buy all the development rights in Jackson Hole.

In theory the solution to the problem is obvious, but its practical application is far less evident. Congress should acquire and pay for all the development controls it needs, minus the value of the controls that the local community would be willing to impose on itself in the absence of federal acquisition. It is easy to construct this value in theory, but not obvious how to measure it in fact, or how to effectuate it.

The question is how much the existing landowners value the maintenance of the community in its present state. They ought to bear the cost of preserving that value. Congress should pay only for the additional amount of protection that represents the distinctive protective needs of the park.

The situation can be illustrated in relation to Jackson Hole. As: sume that the current market value of an acre of land is $\$ 5,000$, of which $\$ 500$ represents its value for grazing (its present use), and $\$ 4,500$ its value for development. Assume further that the federal government has purchased the full fee interest in that acre, paying $\$ 5,000$ and re-

66. H.R. 9135, 95th Cong., Ist Sess. (1977). 
moving the landowner. It has then imposed restrictions on the land to prevent all development that would be incompatible with the park. The next step would be to auction off that acre as restricted. It is possible that no one would bid more than $\$ 500$ (the value solely as grazing land), but it is much more hikely that a number of people would put a considerably higher value on the right to continue ranching on land at the foot of the Tetons, in a community protected against urbanizing influences. If, for example, the former owner would be willing to bid $\$ 1,500$ an acre to stay on his land-with the restrictions-we would have an exact measure of the value to him of the right to live in such a restricted community, and we would also know the additional value $(\$ 3,500$ per acre) that accrued solely to National Park protection. The $\$ 1,500$ represents what people in the community are willing (absent the prospect of purchase by the federal government) to impose on theinselves. It is the value to them of the land with restrictions. The federal taxpayer should only have to pay the difference between that $\$ 1,500$ and the full value of $\$ 5,000$. Such an arrangement would permit the landowner who puts no particular value on staying in a restricted community to take his full $\$ 5,000$ an acre and leave. It would also permit him to stay, if he wishes, but only if he were willing to match or outbid others who also valued staying in such a community.

At first glance, such an arrangement might seem unfair to the landowner, who is forced to pay m order to stay on his own land. After the auction he would be im precisely the same situation that he was before it, but he would be (in this example) $\$ 1,500$ poorer. Yet the situation is neither unfair nor unprecedented. Landowners in a community routmely "pay" to stay on their own land, in order to keep both it and surrounding land from development. This is exactly what happens when a local community zones its lands for anything less than the highest possible economic development. The justification for such selfimposed zoning is that the restrictions benefit landowners in the community as a whole. Indeed, that is the only reason why a counmunity ever obtams majority support for zoning. The difference in our example is that the landowner is forced to make the decision at a time chosen by the federal government rather than by himself or his neighbors. While that constraint is obviously undesirable from the owner's perspective, he always has the choice of taking his full $\$ 5,000$ in cash.

There is precedent for such an arrangement. In a number of national parks, Congress has enacted laws that force communities to choose between enacting zoning that is fully coinpatible with what

67. See note 5 supra. 
the Park Service wants or having their land condemned. ${ }^{67}$ The landowners must either sell out under condemnation, or accept a reduction in value equal to the restraint that the federal government demands. If, as must often be the case, the restraint that the landowner is willing to impose on himself is less than the restraint the parks demand, the owner is pressed to subsidize the National Park system. A strategy such as that recommended above, openly recognizing that some of the restraint the park demands ought to be paid for by the federal taxpayer, is fairer to the landowner.

Furthermore, the arrangement used at some parks, under which landowners have a choice of either enacting the restraint that the parks want without any compensation, or being condemned, will work only where the gap between what the Park Service wants and what the cominunity itself is willing to do is quite small. Landowners willing to impose $\$ 1,500$ an acre restraimts on themselves might be willing to stretch that willingness to $\$ 2,000$ in response to park demands, to avoid the cost and trouble of condemnation and removal, but they are hardly likely to impose $\$ 4,500$ per acre in restraints on themselves, subsidizing the park to the extent of $\$ 3,000$ an acre. This is why such a system will not work at Jackson Hole or in many other places.

An alternative approach exists, in which Congress suspends condemnation authority if acceptable zoning is established, and, if it is not, condemns and leases back to residents for a fixed amount per year the right to remain on the land. This approach is also imperfect. If the worst that can happen to the landowners is that their development rights will be condemned at full market value, and they will in any event be allowed to stay for their lifetimes, there is little incentive for them to zone themselves rigorously. They have inuch more to lose by zoning than they do by allowing themselves to be condemned with a reservation back of a lifetime interest. Moreover, the present system, in which residential uses are reserved back at a fixed rate of one percent of the fee value per year of the reservation, is an extremely crude device. ${ }^{68}$ There is no reason to believe that such a fixed amount accurately measures the value of the right to remam without development opportunities. Assuming, for example, that the average reservation is twenty-five years, the owner would get seventy-five percent of the fee value. In Jackson Hole, using our hypothetical value of $\$ 5,000$ per acre, the owner would be allowed to stay by giving up $\$ 1,250$. If in fact he would be willing to give up $\$ 1,500$, Congress is overpaying him by $\$ 250$ per acre. If he would only be willing to give up $\$ 750$, Congress is underpaying .

68. Land Acquisition Policy 24,794. 
him by $\$ 500$ per acre. There is no good reason to avoid testing the exact amount the landowner is willing to yield to remain on his land.

The scheine proposed here has an additional value. Auctioning off the right to remain on the land encourages the entry into the community of those people who would like to hivc in a place like Jackson Hole, and who are willing to have the community remain as ranch or residential land. If Congress believes that keeping Jackson Hole in its rural state is necessary to park protection, it should encourage people whose lifestyle is consistent with preservation of the park to enter the area. Such an approach would reverse the present undesirable policy that inutely encourages developers and speculators to enter the community.

At the same time, the new policy would not force any existing resident out of the commumity. It would only require residents to decide how inuch they value remaining in such a community, and would force them-not the federal taxpayer - to bear that cost. The policy would also give residents the alternative of leaving with the full market value of their land. It would make clear to them that speculating on future developinent is inconsistent with Congress's policy for the park. Finally, and perhaps least popularly, it would inake clear to residents that their desire to hedge against future uncertainties in the cattle industry (or any other local industry) is not an interest that the federal taxpayer is obliged to subsidize at the expense of the quality of the National Park System.

One potential problem with this arrangement can easily be avoided. Wealthy nonresidents, who like Jackson Hole as it is, may be willing to bid a very high price, even above the $\$ 5,000$ present market value of the land. A present resident should not have to coinpete with an outsider paying $\$ 10,000$ or inore for the right to remain, and under the proposed scheme he need not. At most, Congress need only demand that the present resident yield all his future incompatible developinent rights to the federal government. Thus the present resident would have a choice: bid for the right to stay, paying the maximuin amount bid up to but not exceeding $\$ 4,500$ (the full present value of the fee, mimus the present use value); or donate to the federal government a covenant restricting his development rights according to the government's plans. The resident would then take the course least costly to him. Of course, he would also have the choice of selling out the fee for $\$ 5,000$.

There is, obviously, a serious practical and political problem with this proposal. It would be extremely costly and disruptive for an existing commumity to put all its land up for auction. It would also be difficult to sustain an active market for any large anounts of land all at 
once, or over a short period of time. It would also doubtlessly appear extremely intrusive to local landowners, generating increased hostility toward the federal government, althouglı as I have suggested above, it would be less costly to landowners than the policies that Congress now employs of coercmg restrictive local zoning under the threat of condemnation.

Therefore, this Article suggests a modest alternative plan. Rather than forcing all land into an auction, the federal government could make an estimate of the value to the landowners of the right to remain where they are without development rights. Let us say that a panel of objective and knowledgeable appraisers estimated the fee value at $\$ 5,000$, and the value to landowners of the right to remain with existing ranching uses, in a nondeveloping community, at $\$ 1,500$. Congress would then offer to each landowner the alternative of accepting $\$ 5,000$ in exchange for his fee interest, or $\$ 3,500$ for his development right (fee value of $\$ 5,000$ reduced by $\$ 1,500$ ).

If landowners think the estimate is too low, they can take their $\$ 5,000$ and leave. Because the government lias an interest in encouraging them to stay (the alternative is for the government to manage a lot of land it really does not want, or to find new purchasers) there will be a considerable incentive for the government to inake an offer that the landowners will find attractive. And as long as the alternative of full condemnation is credible, landowners will have an incentive to accept a reasonable offer. To give even further assurances, the government could offer a third alternative to the landowner. If a landowner is suspicious of the government's estimate, the government can offer him the clioice of putting his land up for auction. If no one offers inore than the $\$ 1,000$ for the right to remain, for example, the landowner will be allowed to stay by matching the $\$ 1,000$ bid. If, on the other liand, soineone offers $\$ 2,000$, he will have to pay $\$ 2,000$ to remain. He will thus have the opportunity to test the value of the interest in remaining, rather than acquiescing in the government's estimate. The landowner will be deterred from lightly demanding an auction by the risk that if he guesses wrongly, he will have to bear the burden of his inisjudgment.

Plainly such a plan will be useful only in those cases where landowners put some value on the right to remain on land witl less development than the market would permit. If, as is true in sone places, the landowners are willing to lave unrestrained development, the only option open to the government is to acquire incompatible developinent rights at full cost. That is as it sliould be, for in such cases only the 
Park Service values the restraints, and therefore the federal taxpayer should bear the cost of them. ${ }^{69}$

One situation in particular deserves mention. In areas where the Park Service wants restraints, but the landowners are unwilling to impose any, development is merely deeined to be illegal. For example, developinent inay be subject to the obtaining of a permit froin the Corps of Engineers. ${ }^{70}$ If the permits are not granted, there will be no incompatible development. But it is not clear, prior to the imitiation of development, whether permits will be granted or not. Such situations present a dilemma for the Park Service. If the land is acquired, the Park Service is criticized for wasting public funds on unnecessary acquisitions. If the land is not acquired, and subsequently development plans do go forward, the Service may have lost the chance to deter uses that harm the park, or may find the price of condemnation at that late point to be excessive. There is no obvious solution to this problem. One possibility is to pursue the policy of early acquisition, arguing in a valuation proceeding that in calculating just compensation the full use value must be discounted by the unlikelihood that a permit will be granted. ${ }^{71}$ Another alternative is to wait, and then participate vigorously in any future permit proceeding, arguing strongly for the demal of the permit. Neither possibility is clearly superior, but certainly early acquisition, combined with a strong effort to discount the cost on the ground that permits are unlikely to be issued, is the most protective posture for the parks.

\section{CONCLUSION}

As a matter both of cost minimization and of fairness to landowners, a policy of early acquisition of lands that are subject to development incompatible with parkland is desirable. This policy should not distimguish between old and new parks im regard to lands within park boundaries, nor should it distimguish between lands within and outside park boundaries. The policy would only distinguish: (1) between lands needed by the parks for basic resource protection, administrative purposes, or visitor use, which should be acquired in fee; and those where the only need is to insulate basic resources or uses, where developinent

69. Of course this is not to suggest that the federal government should hesitate to sue to prevent developmeuts that reach-or even approach-the level of nuisances, as it should have done at Gettysburg National Military Park some years ago. See Sax 240 n.8, 248. The government should also stand ready to sue to protect its property rights, such as water. See, e.g., Cappaert v. United States, 426 U.S. 128 (1976).

70. This problem is discussed in The Federal Drive to Acquire, supra note 9, at 58.

71. See United States v. Virgimia Elec. \& Power Co., 365 U.S. 624 (1961), in which the court states: "[T]he value of the easement is the nonriparian value of the servient land discounted by the improbability of the easement's exercise." Id. at 635 . 
rights or easements or some other lesser interest should be acquired; and (2) between lands where potentially incompatible use requires acquisition to protect the parks, and those lands where-because of other national policies or because local or regional development is deemed more important than park protection-incompatible uses should be tolerated. A survey of lands both within and near park boundaries should promptly be made to identify those lands that, if developed, should be acquired to protect the parks. ${ }^{72}$

As to those lands where acquisition is desirable, the plan suggested above, calculating the interest of landowners in remaining on their land with development restrictions, should be implemented im order to determine the appropriate burden that can be imposed on landowners by way of a surrogate for local zoning. Such a plan will signifieantly reduce the cost of acquiring those interests in land that ought to be acquired.

The problems of parkland acquisition and control, of course, cannot be resolved simply by fee acquisitions, expanding park boundaries, and adding new lands to existing parks. ${ }^{73}$ To a significant extent the problein centers on the existence of adjacent lands, and there will al-

72. One interesting datuin produced by the Superintendent Survey, supra note 5, is that most park inanagers are able to identify specific, and rather limited, acreages outside their boundaries that they view as particularly threatening, and on which some form of land use controls would provide the protection they need. Of course, some of the problems are not subject to resolution as a matter of National Park policy, such as the issues of western energy developinent or undesirable developinents in major cities. Soine problems will only be dealt with through congressional control under the Clean Air Act, for example, or through congressional supervision of other federal agencies, such as the Bureau of Land Managenent or the Forest Service. Obviously nothing in this Article can respond to the concerns expressed by the superintendent at Big Thicket National Preserve who noted that "with over 400 iniles of boundary scattered over 2,500 square miles, we could be threatened by actions on well over a million acres"; or by the superintendent at Mesa Verde National Park who saw all regional development within an area of 200,000 acres as a threat; or at Everglades National Park, where it is now very late for the federal government, as a matter of park policy, to control the 300,000 acres in South Florida that dominate the water systein critical to the park. Superintendent Survey, supra note 5.

Nonetheless, enough superintendents identified specific outside lands that need to be controlled to make the proposals made here worth considering. While the figures for acquiring the necessary interests are obviously extremely rough, the survey gives soine order-of-magnitude ideas. For land outside boundaries, excluding extraordinarily large tracts like those at Big Thieket or Mesa Verde, and extraordinarily expensive urban tracts at places like Lowell National Historical Park, I estimate the total cost to be around $\$ 2$ billion.

Park inanagers do not regularly monitor land values for outside tracts that threaten the parks. Until developinent is imminent and an appraisal is made looking toward purchase or condemnation, land values are not a matter of official concern. As of 1976, the 36,000 acres of "inholdings," private lands within pre-1959 parks, were valued at \$106 million. Hearings 271.

73. Sax 251. As the superintendent at Big Bend National Park observed: "[W]e do not propose acquiring another 150,000 acres of land-this would only continue to expand the boundary endlessly." Letter from Robert C. Haraden, Superintendent, to the author, Ref. No. L1415 (Mar. 3, 1980). 
ways be new lands adjacent to any new boundary. The goal should be to insulate parks with compatible private uses, such as ranching at Jackson Hole, through less-than-fee acquisitions, use of local zoning, or regulation or hitigation of illegal conduct, leaving private owners to serve as buffers.

In pursuing these plans, Congress should recognize that parkland acquisitions are a capital cost, and that a dollar saved this year, but expended as six dollars ten years hence, is surely no saving at all. The policy of proinpt acquisition should be implemented only as long as it is reasonably likely that land values will contmue to rise more rapidly than the interest rate.

Finally, a word should be said about the pohtical implications of the strategy proposed here. Deferring acquisitions until threats are imminent and treating eacli problem individually when it arises enhance the ability of influential landowners in each community, and of individual members of Congress in each district, to influence park policy. Obviously, certain individuals are greatly benefited if an exception is inade in their case and they are allowed to go forward with incoinpatible developinents, or if their lands are ultimately condemned at the highest possible price. But to recognize these political implications is hardly to suggest that they inake sense as an element of National Park policy, or that they should be tolerated by federal taxpayers and park users.

The National Park Service also has an interest in maintaming friendly relations witl neiglıboring landowners. Park superintendents do not readily argue that the investinent opportunities of their private neiglibors should be cut off, or that desired local development should be foreclosed. Only the Congress, by adopting policies of general application, can insulate the Park Service from the intense pressure it receives from private landowners. The Park Service has sometimes worsened the problem itself by indicating a desire to buy in fee more land than it actually needs, and by getting rid of compatible private uses, when acquisition of the lesser interest of a development right would serve its needs effectively. The Park Service has thus helped to create an undesirable and unnecessary alliance between existing residents, whose presence is frequently compatible with a park, and inere investors. Such alliances do not favor the park system, and the policies proposed here would help sever them. ${ }^{74}$

74. This very same distinction between pre-existing coinpatible residents and speculators has been made by some members of Congress, but the distmction is not yet as evident in policy practices as it should be. See Hearings 192-93. A special problem is presented by undeveloped residential lots in already developed inholding communities. The assumption seems to be that 
The real losers from the inadequacies of present policy are small landowners, park users, and federal taxpayers. The time is right for thein to urge Congress to take a fresh, long, and hard look at current land acquisition practices.

allowing any further developinent within park boundaries is highly undesirable. Perhaps the concern is that residences within a park are an unfair benefit for a very small number of citizens. $I d$. 272. There is also a problein of long-standing not-yet-fulfilled expectations by lot owners. See National Park Service, U.S. Dep't of the Interior, Olympic National Park, Draft LAND ACQuisition PlaN 5-6 (1979) (Lake Crescent Shoreline). 